\title{
Asymmetric Information and Islamic Financial Contracts
}

\author{
Abdelhafid Benamraoui ${ }^{1} \&$ Yousef Alwardat ${ }^{2}$ \\ ${ }^{1}$ Westminster Business School, Westminster University, UK \\ ${ }^{2}$ Faculty of Economy \& Administration, King Abdulaziz University, KSA \\ Correspondence: Yousef Alwardat, Faculty of Economy \& Administration, King Abdulaziz University, KSA. \\ E-mail: wardat61@yahoo.co.uk
}

Received: November 11, 2018

Accepted: December 7, 2018

Online Published: December 18, 2018

doi:10.5539/ijef.v11n1p96

URL: https://doi.org/10.5539/ijef.v11n1p96

\begin{abstract}
This research paper aims to examine the relevance of asymmetric information to the two main financial contracts used by Islamic banks or conventional banks with Islamic windows, mudaraba and musharaka. We use theoretical proofs to explain how asymmetric information affects mudaraba and musharaka contract in terms of bank cost and yield and how to account for the adverse selection and moral hazard costs when calculating bank net profit or loss. We also provide suggestions supported by key modern theories including signalling, comparative advantage and incentives to resolve asymmetric information problems in the Islamic financial contracts. The research paper shows that asymmetric information is relevant to both mudaraba and musharaka contracts and directly affects Islamic banks and conventional banks with Islamic windows cost and yield. The paper also reveals that signalling and incentives are effective tools to deal with asymmetric information in Islamic financial contracts. Finally, the paper shows that Islamic finance providers need to opt for more secure financing, particularly with small borrowers.
\end{abstract}

Keywords: asymmetric information, Islamic financial contracts, signalling, comparative advantage, incentive theory

\section{Introduction}

Since the work of Stiglitz and Weiss (1981) a number of research articles were devoted to the analysis of the relationship between asymmetric information and firm financing and investment decisions (Berger et al., 2011; Greenwald \& Stiglitz, 1990; De Wet, 2004; Pike et al., 2005; Nyoni, 2018). These studies used mainly conventional financial markets and companies' data and facts in their investigation of the relevance of asymmetric information to modern financial contracts with limited attention being paid to Islamic financial products.

The consensus among the scholars is that asymmetric information can take place either before or after the financial contract is issued (Liu, Margiritis, \& Tourani-Rad, 2011; Miskin; 1999; Morellec \& Schürhoff, 2011). The first type of asymmetric information is the result of holding information that is unknown to at least one party involved in the contract and makes the individual or organisation who hold the information have an advantage or receive any form of benefits, which would have not been received if the information was known to all parties involved in the contract. This type of asymmetric information leads to adverse selection of products or services offered by the firms (Knutsen, 2001). Fund raisers and investors are likely to suffer from this problem in a situation where information asymmetry left unmanaged (Abosede \& Oseni, 2011). The second type of asymmetric information is the result of taking an advantage of holding specific information after the contract has been agreed or exercised. Both types of asymmetric information are said to lead to inefficient allocation of capital, adverse selection of investments and to problems of moral hazard (see for example De Wet, 2004).

Islamic finance and its main principles have been subject to extensive research both theoretically and empirically (see for instance: Chong, 2009; Berg, El-Komi, \& Kim, 2016). The scholars accepted definition of Islamic finance is a form of finance, which follows the values set by the Sharia or the Islamic law (Gheeraert, 2014). The tenets of the Sharia include principally the prohibition of accepting interest rate (riba), investing in certain sectors or products, such as alcohol, tobacco, pork and weapons, and engaging in speculative or gambling activities. The other fundamentals of Islamic finance are applying profit and loss sharing and avoiding excessive uncertainty or gharar (Medhioub \& Cahffai, 2018). The application of these principles necessitates the fair 
distribution of information between the parties involved in Islamic financial contracts. As a result, asymmetric information becomes very important element in judging the validity of these contracts, which is why in this research we attempt to provide further theoretical evidence and insights on this topic.

In addition, the problem of asymmetric information in Islamic finance, particularly with reference to mudaraba and musharaka contracts, is still not well explored both theoretically and empirically and this study intends to fill such gap. By providing theoretical evidence for the asymmetric information in each of these two contracts we unveil how asymmetric information affect the bank yield and results in more costs to the bank both at the ex-ante and ex-post stages of the lending process. We also explain how to account for the adverse selection and moral hazard costs when calculating bank net profit or loss. The paper then uses a number of conventional theories to provide solutions to the asymmetric information problem observed in Islamic financial contracts. These theoretical discussions presented will provide platform on which future empirical studies on asymmetric information in Islamic finance can build on.

The remaining of the article is organised as follows. After presenting the main themes emerging from the literature review on asymmetric information we discuss to what extent gharar increases the level of asymmetric information in financial contracts and what counts as gharar. A theoretical model is then developed for the two main Islamic financial contacts, mudaraba and musharaka, to show how asymmetric information affects each contract. In the next section we discuss the main theories that can be adopted by Islamic banks or conventional banks with Islamic windows in order to deal with asymmetric information. The last section concludes and summarises the key points presented in the research article.

\section{Literature Review}

\subsection{Asymmetric Information and Capital Market}

The early literature on asymmetric information is mainly geared towards the understanding of investment and credit distribution behaviour when different players involved in the investment and financial contracts have different access to company's inside information (Stiglitz \& Weiss, 1981; Myers \& Majluf, 1984; Miskin, 1990). This literature shows that an increase in interest rate ceiling creates a gap in the demand and supply of capital leading to possible acceleration in credit and investment rationing. Such rationing is directly influenced by the asymmetric information element.

When the information about the borrowers is not complete and the interest rates are high the lender finds difficulty in distinguishing between good and bad borrowers leading to adverse selection as high risky borrowers are more likely to receive loans and accept to pay high interest rates (see Stiglitz \& Weiss, 1981). The failure of these borrowers to repay their interest and capital sum leads to decline in money supply, which triggers further increase in the level of interest rates causing a domino effect on the whole capital market. A seminal work by Steijvers and Voordeckers (2009) demonstrate that contractual relationship between borrowers and lenders is characterized by the presence of asymmetric information that may give rise to credit rationing. The asymmetric information is found to be a contributing factor to the rise in the bank expected rate of return non-monotonously when an increase in the interest rate occurs. Hence, most banks would choose to ration credit to opaque firms than raise the interest rate. In such cases, collateral would be a vital tool for the bank to mitigate informational asymmetries, thereby resolving the credit-rationing issue. If the interest rate proves ineffective due to indirect effects on the average quality of the credit portfolio, the collateral would be useful in protecting the bank from asymmetric information.

\subsection{The State of Economy}

The status of the economy is also considered as key driver of the extent of asymmetric information in lending. A study by Ordoñez (2013) shows that in good economic conditions lenders charge low interest rate as business ventures become profitable and most borrowers repay their loans. This provides positive signals to lenders to extend more credit to the economy. In contrast, when the economic environment worsens firms have high probability of failure. The information generated on the failing business ventures allow lenders to easily infer that economic conditions have changed, and as a result raise rates quickly in order to account for the higher probability of default by the borrowers. Then when the economy is turning to recovery again the lenders only reduce their rates gradually and minimally due to few signals received from the limited number of business ventures that survived the economic downturn. Such situation makes the lenders learn slowly about their borrowers financial prospects. He claimed that the asymmetric movements of lending rates is brought about by this endogenous learning process, translating into asymmetric movements of investment and output. 


\subsection{Equity Financing}

In equity financing, asymmetric information has been linked to unfair pricing of listed companies' stocks, particularly in markets exhibiting weak form of market efficiency, such as those located in emerging economies (i.e. Ciner \& Karagozoglu, 2005). This is supported by Shekari and Jamshidinavid (2017), they claim that market effectiveness, which based on existed information in the market has an effect on stock prices. In addition, in an influential study by Myers and Majluf (1984) they find that when investors are unable to differentiate between the issuers of equity in terms of their quality, due to asymmetric information, the firms become subject to unfair pricing of their stocks with high performing companies being under-priced and low performing firms being over-priced. The outcome of such market conditions is the non-issue of stocks by high performing companies, which leads to cancellation of some of their good investment projects (See Bayless \& Dilz, 1991 for detailed review of literature on asymmetric information and firm choice of financing).

However, a later study by Fama and French (2005) show that a firm can actually issue equity when it is subject to adverse selections through the use of information signalling. Frank and Goyal (2003) also revealed that small firms with high growth prospects are more likely to use equity than debt without taking into account the effect of asymmetric information.

\subsection{Investment Decisions by Firms}

Investment decision is another sphere directly linked to the problem of asymmetric information. Morellec and Schürhoff (2011) developed a dynamic model to count for the effect of asymmetric information on firms' investment decisions and similar to the approach suggested in our theoretical framework their sample companies have been classified into two categories, good and bad, using firms' cash flow stream. Their results reveal that the cost of financing investments in a firm is directly affected by the level of asymmetric information. When asymmetric information is high the cost of capital increases forcing good companies to delay their projects. This is supported by the findings of Shibata and Nishihara (2012) who examined the contribution of managers in terms of time in the existence of asymmetric information between the owners and the managers. Their findings indicate that investment timing is delayed by the owners more in the presence asymmetric information than symmetric information. This is because a part of the underlying state variable is privately observed by the managers, while it is unobservable by the owners. Managers with private information have a natural tendency to bring forth false reports and then divert free cash flow to their own benefits. Likewise, Grenadier and Wang (2005) results support the view that moral hazard leads to late investing by firms. Bad companies, however, are found to be more likely to take their investments even with high cost of capital leading to investment distortion.

Investment and financing decisions are also viewed to be simultaneously driving the level and timing of firms' information release. Hennessy, Livdan, and Miranda (2010), for example, analysed both investment and financing decisions in an environment where information signalling are given at different time intervals and the information only apply for a short period of time. Their results reveal that companies use information related to financial decisions rather than investment decisions even if bad companies have less use of debts compared to good ones.

Research on asymmetric information is further extended to financial firms. Among the financial firms banks are found to have the necessary skills to collect and process what is perceived to be the inside information about borrowers, which enable them to reduce the likelihood of adverse selection and moral hazard caused mainly by the existence of information gap between the banks and their clients (Liu, Margaritis, \& Tourani-Rad, 2011). Such information is usually obtained by having a long term financial relationship with the borrowers. A study by James (1987) documents that servicing cost of banks' loans and their principal sums also provide a good signal to other investors and lenders about the ability of borrowing firms to meet their financial obligations.

Among the parameters that have been used by scholars to account for the effect of asymmetric information in banks is their size. Phylaktis and Chen (2010), for instance, test if top trading banks which possess superior information and process high flow of data do help them collect the scattered pieces of information and sense the general movements of the economy. They found that the top 10 banks, out of 100 banks that had quotes in the foreign exchange market, had a monthly average share of over $70 \%$ of the total market information, and around $80 \%$ during some US macro-announcements. These results suggest the importance of bank size in accessing more information and therefore reduce the effect of asymmetric information. This is captured by our theoretical model where bank size is taken as a control variable in predicting the effect of asymmetric information on mudaraba and musharaka contracts.

Tax is among the parameters also linked to asymmetric information. In a study by Lin and Zen (2017) they demonstrated theoretically how asymmetric information influence actions taken by the tax department in a firm 
that designs optimal incentive contracts. They argued for the use of third party information to identify the level of risk in the contracts and use this as a base in order to lower the cost of the tax department. However, this is less relevant to Islamic finance contracts at least in theoretical sense as Islamic firms including banks are only required to pay zakat (form of levy set at $2.5 \%$ of the individual or firm's wealth after deducting the necessary costs and expenses).

\subsection{Size of the Enterprise}

Finally, a number of studies have been devoted exclusively to the issue of asymmetric information in the case of small and medium size enterprises (SMEs). Petersen and Rajan (2002), for instance, carried out their research on the USA market and finds that availability of information on SMEs credit history and ability to process them quickly result in better access to credit by SMEs as lenders become more informed and hence make prompt decisions on granting credit to SMEs. Focusing on New Zealand market Liu, Margaritis and Tourani-Rad (2011) find that alterations in the banking funding costs are directly influenced by the element of asymmetric information. Their results also endorse the notion that business loans are more subject to asymmetric information than mortgages. In the seminal work by Bondt (2002) he examined the relationship between asymmetric information and the level of interest rate and found that lenders adjust their lending rates to SMEs to compensate them for the costs related to the element of asymmetric information.

Consistent with our theoretical approach and reasoning, in focusing on the main financial contracts forming Islamic banks' portfolio, research shows that banks attitude towards collecting information about SMEs is directly linked to bank portfolio and its size of lending to SMEs. Liu, Margaritis, and Tourani-Rad (2011), for example, conclude that banks have less interest in collecting information about SMEs in New Zealand as banks perceive such approach not financially worthwhile and instead use collateral, which results in a possible credit rationing and high cost of borrowing.

On the whole, the literature shows that asymmetric information has paramount effect on the financing and investment decisions of a firm as well as the lending and borrowing function of a lending institution such as a bank. The extent of information availability also varies across borrowers and from one banking product to another. This has ultimately created divergence in the way conventional banks respond to the challenging presence of asymmetric information. In the next section we extend our analysis to address the question of how asymmetric information applies to Islamic financial contracts.

\section{Asymmetric Information in the Islamic Finance Context}

In Islamic finance context the main concept related to asymmetric information is gharar. As the Quran and the saying of the Prophet did not refer to just one case of gharar a number of definitions exist for the concept (Ahmad, 2004; Nordin et al., 2014). Al-Darir (2004) divides the definitions given by scholars to gharar to three clusters. First, gharar occurs when there is a doubt or uncertainty as to whether the transaction occurs or not. Second, gharar is the outcome of ignorance (jahalah) of the object. Third, gharar refers to contracts or objects which have unknown or doubtful characteristics, and this view is held by most of the scholars.

From a business perspective gharar refers to a sale or a contract, which is considered either risky or unsafe. This occurs when the details related to the sale of the commodity or the item are not known with certainty. Gharar is strictly prohibited elements under Islamic precepts as it is perceived to be unfair for at least one party with the sale contract to be exposed to excessive risk (Nehad \& Khanfar, 2016). It is also causing harm to the society since it results of speculation, immorality, inflation, instability and environmental degradation (Paldi, 2014; Nehad \& Khanfar, 2016). Therefore, there are stringent rules applied to transactions following Islamic paradigm of financing before they are deemed to be acceptable.

Gharar in Arabic language terminology means deception (see Thomas, 1995) as a result of lacking knowledge of the item being exchange between the parties. In the context of trade, both real and financial, gharar is attributed to not knowing the fair value of the item exchanged or the conditions of the object subject to sale.

The elements of gharar are observed in modern financial contracts and services offered by banks (Thomas, 1995). The risk and return are not fairly quantified and distributed between the depositors, financial intermediaries and borrowers as each party does not have the same access to information as well as the same ability to assess the risks related to the investment of the funds. The absence of complete information results in mispricing of banking products and for banks attracting the wrong type of borrowers.

As depicted in figure 1 below gharar can be the outcome of insiders having access to special information allowing them to have an advantage and result in a direct harm to the outsiders at one stage during the selling of the physical or financial item. The outsiders are also likely to be in a position of not being able to determine the 
real factors affecting the financial item price or to be unaware of the true characteristics of the item being priced due to lack of information.

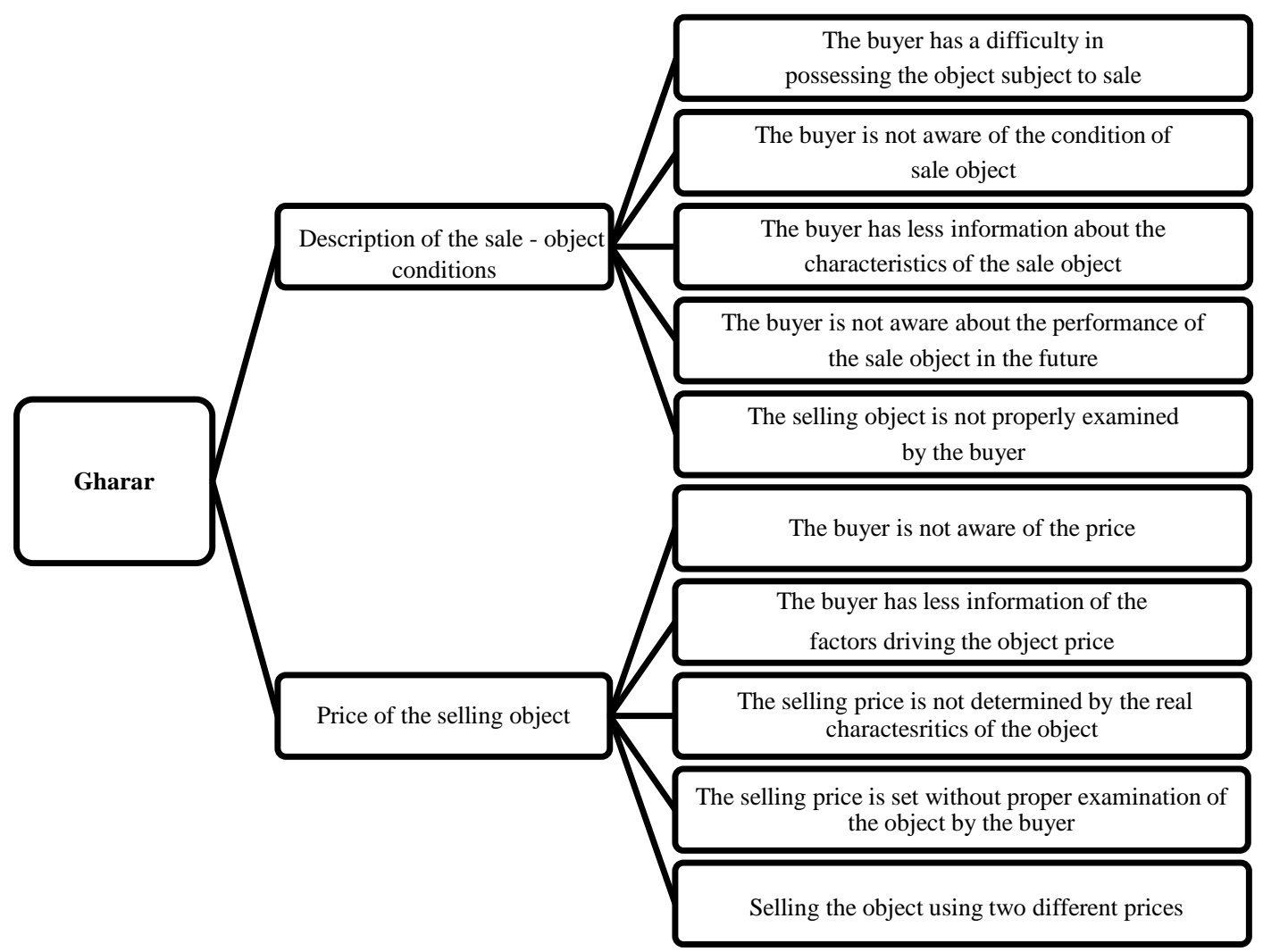

Figure 1. Causes of Gharar in trade contracts

In investment context gharar refers to situations where the investor(s) has insufficient information or knowledge about the entity or project funded by his own money or through borrowing. This usually occurs as a result of not taking all the necessary measures and not entering into a comprehensive contract(s) that fully protect the interest of all the parties involved in the financing of the project. Problems of uncertainty about the contract terms or the project also contributes to gharar in investments (Ayub, 2007; El-Gamal, 2006).

In Islamic financial contracts the level of asymmetric information tends to vary from one contract to another. Nagaoka (2010) states that one of the main reasons partnership (musharaka) based contracts are less attractive is the high asymmetric information attached to these contracts compared to other financial agreements. High banking reserves and capital provide more assurance to banks against asymmetric information, particularly for those who are placing their funds under less restricted financial contracts like mudaraba.

An investment behaviour which contains elements of gharar and ignores the realm of business activities does not create economic value and rather destroys wealth (Al-Suwailem, 2006). This is apparent in many modern financial contracts where, at the point of termination of the product life, no real value is created and instead one party incurs losses at the expense of the other.

Although gharar is perceived to be one of the main principles of Islamic finance, it is thought that complete contracting is intrinsically impossible (i.e. Yasushi, 2013), as all contracts are bound to include some uncertainty with regard to the object of the contract. However, the problem facing Islamic finance advocates is that the extent of uncertainty that makes any transaction forbidden had not been clearly defined (Ayub, 2007, p. 58). This has made many scholars to agree that minor gharar is acceptable as the element of risk cannot be fully eliminated in trade and other forms of business (see for example: Al-Suwailem, 2006). Al-Saati (2003) also mentions that the Hadith prohibiting gharar is not aimed at prohibiting all methods of gharar but rather gharar which is likely to create disagreements and hence cannot be acceptable. A minor gharar takes place when the business or contract produces an outcome, which is deemed to result in more economic and social benefits than the negative implications it creates to the transaction participants. 
A number of measures are proposed to account for gharar. This includes the zero-sum approach and the probability based model (Al-Suwailem, 2006). The zero-sum model considers the outcome of individual decisions to the parties involved in the contract. Gharar occurs when one party benefits at the expense of other contract participants without producing real economic gains. The probability based model instead tests the likelihood of an outcome(s) to take place and how risky is each outcome. In this paper the probability based model is used to explain how asymmetric information affects the two main Islamic financial contracts, mudaraba and musharaka. Mudaraba is defined as a contract whereby the bank is responsible for financing whilst the client is responsible for management. The profit generated from the project is shared between the bank and the client. The bank bears any losses incurred in the project. Musharaka is partnership agreement between the bank and other parties to participate in the management and financing of a joint enterprise. In musharaka the profit and loss are shared between the parties involved in the contract on a pre-agreed basis.

\section{Theoretical Evidence}

We consider three assumptions in formulating the theoretical evidence for asymmetric information in the Islamic banks or conventional banks with Islamic windows main financial contracts, mudaraba and musharaka. First, similar to conventional banking not all parties (bank, investors and borrowers) have the same information. Second, the loan agreement parties have less than perfect information. Third, some parties to the loan agreement have inside information, which is not made available to the other sides of the contract.

We divided bank borrowers to two groups, good borrowers and bad borrowers. Bad borrowers repay the loan with probability of zero and good borrowers repay the loan with probability of one. A borrower is considered a bad one if he hides relevant information before receiving the loan or engages in risky activities when the loan is granted.

To calculate the bank expected profit or loss we use four propositions, two for each type of financial contract. The type of borrower denotes if the asymmetric information is present in the contract or not. As we follow the probability based approach the use and distribution of profit is defined under each proposition. The theoretical demonstration then goes into showing how to calculate net profit and loss taking into account all the costs associate with asymmetric information.

\subsection{Asymmetric Information under Mudaraba Contract}

\section{Proposition 1: Mudaraba Contract is with Good Borrower}

Suppose we have a good borrower $B_{G}$ who needs to fund a project requiring up-front payment of $P_{0}$. The project is fully financed by the bank and generates either zero or $\frac{3}{2} P_{0}$. gross return with equal probability of 0.5 .

The profit incurred from the project is distributed equally between the bank and the borrower.

The borrower needs to provide collateral of $C=\frac{P_{0}}{2}$ deposited with the bank.

The bank expected profit will be:

$$
\begin{gathered}
E \Pi_{B}=\frac{1}{2}\left[0-\frac{P_{0}}{2}\right]+\frac{1}{2}\left[\frac{3 P_{0}}{2}-r P_{0}\right] \\
E \Pi_{B}=\frac{P_{0}}{2}-\frac{r P_{0}}{2}
\end{gathered}
$$

The bank yield is:

$$
\frac{P_{0}}{2}-\frac{r P_{0}}{2} \geq 0 \Rightarrow r \leq 1
$$

\section{Proposition 2: Mudaraba Contract is with Bad Borrowers}

Suppose we have a bad borrower $B_{B}$ who needs to fund a project requiring up-front payment of $P_{0}$. The project is fully financed by the bank and generates either $-\frac{P_{0}}{2}$ or $2 P_{0}$ gross return with probability of 0.75 for the first outcome and 0.25 for the second outcome. This is different from the first proposition in which the borrower generates equal or more than zero gross return and with high probability given to negative gross return to 
account for the borrower as being a bad one. The profit from the project is distributed equally between the bank and the borrower. The project losses are fully taken by the bank.

The borrower needs to provide collateral of $C=\frac{P_{0}}{2}$ deposited with the bank.

The bank expected loss will be:

$$
\begin{gathered}
E \Pi_{B}=0.75\left[-\frac{P_{0}}{2}-\frac{P_{0}}{2}\right]+0.25\left[2 P_{0}-r P_{0}\right] \\
E \Pi_{B}=-\frac{P_{0}}{4}-\frac{r P_{0}}{4}
\end{gathered}
$$

The bank yield is:

$$
-\frac{P_{0}}{4}-\frac{r P_{0}}{4} \geq 0 \Rightarrow r \leq-1
$$

The two propositions above show that the bank yield turns negative under the second proposition where the borrower is bad one. The negative yield is assumed to be the result of losses incurred with the bad borrower under the influence of asymmetric information, which first translated into negative gross return then into negative yield.

\subsection{Asymmetric Information under Musharaka Contract}

\section{Proposition 3: Musharaka Contract is with Good Partner}

Suppose we have a good partner $P_{G}$ who has a musharaka contract with a bank each contributing $\frac{1}{2}$ to the funding of a project, which needs total cash outlay of $P_{0}$. The project generates either zero or $\frac{3}{2} P_{0}$ gross return with equal probability of 0.5 . The profit and loss incurred from the project is distributed equally between the bank and the partner.

In case of the success of the project the bank expected net profit will be:

$$
E(\Pi)_{B}=\frac{1}{2}\left[\frac{3 P_{0}}{2}-P_{0}\right]=\frac{P_{0}}{4}
$$

If the project does not succeed, expected net loss of the bank will be:

$$
E(\Pi)_{B}=\frac{1}{2}\left[0-P_{0}\right]=-\frac{P_{0}}{2}
$$

The average expected net profit or loss taking into the probability of each scenario is:

$$
E(\Pi)_{B}=\left[\frac{1}{2} * \frac{P_{0}}{4}\right]+\left[\frac{1}{2} * \frac{-P_{0}}{2}\right]=-\frac{P_{0}}{8}
$$

\section{Proposition 4: Musharaka Contract is with Bad Partner}

Suppose we have a bad partner $P_{B}$ who has a musharaka contract with a bank each contributing $\frac{1}{2}$ to the funding of a project, which needs total cash outlay of $P_{0}$. The project generates either $-\frac{P_{0}}{2}$ or $2 P_{0}$ gross return with probability of 0.75 for the first outcome and 0.25 for the second outcome or $\frac{3}{2} P_{0}$ gross return with equal probability of 0.5 . This is different from the previous proposition in which the partner generates equal or more than zero gross return and with high probability given to negative gross return to account for the partner as being a bad one. The profit and loss incurred from the project is distributed equally between the bank and the partner. In case of the success of the project the bank expected net profit will be: 


$$
E(\Pi)_{B}=\frac{1}{2}\left[2 P_{0}-P_{0}\right]=\frac{P_{0}}{2}
$$

In case of the failure of the project the bank expected net loss will be:

$$
E(\Pi)_{B}=\frac{1}{2}\left[-\frac{P_{0}}{2}-P_{0}\right]=-\frac{3 P_{0}}{4}
$$

The average expected net profit or loss taking into the probability of each scenario is:

$$
E(\Pi)_{B}=\left[\frac{1}{2} * \frac{P_{0}}{2}\right]+\left[\frac{1}{2} * \frac{-3 P_{0}}{4}\right]=-\frac{P_{0}}{8}
$$

As shown above when the musharaka contract is taken with bad partner the average expected net profit remains unchanged but the expected loss is greater. The expected loss is assumed to be the result of asymmetric information, which first translated into negative gross return for the bad partner then into average net loss for both partners.

The full expression used to calculate the expected net profit or loss for the bank is given below:

$$
E(\Pi)_{B}=\left[P_{\text {Success }} * P R_{s}\left(G R_{s}-C_{\mathrm{Pr}}\right)\right]-\left[P_{\text {Failure }} * L R_{F}\left(G L_{F}-C_{\mathrm{Pr}}\right)\right]
$$

Where: $P_{\text {Success }}$ indicates the probability of success of the project; $P R_{S}$ is profit rate of the bank in case of success; $G R_{S}$ is the gross return for a successful project; $C_{P r}$ is the cost of the project for the bank; $P_{\text {Failure }}$ is the probability of failure of the project; $L R_{F}$ is the loss rate of the bank in case of failure; $G L_{F}$ is the gross loss for a failed project.

The total cost to the bank is made of five components, three costs at the ex-ante stage and two costs at the ex-poste stage of financing the project (see figure 2 below). The weighting of these costs may vary from one bank to another, particularly for cost of finding the counterparty and enforcement costs. These costs are incorporate into equation 1 above to arrive at the expected net profit or loss for the bank as expressed in equation 2 below:

$$
E(\Pi)_{B}=\left[P_{\text {Success }} * P R_{s}\left[G R_{s}-\left(C_{s c}+C_{o i}+C_{n c}+C_{m}\right)\right]\right]-\left[P_{\text {Failure }} * L R_{F}\left[G L_{F}-\left(C_{s c}+C_{o i}+C_{n c}+C_{m}+C_{e}\right)\right]\right.
$$

Where: $C_{s c}$ is the cost of searching for the counterparty; $C_{o i}$ is the cost of obtaining information about the counterparty; $C_{n c}$ is the cost of negotiating the contract; $C_{m}$ is the cost of monitoring the borrower; and $C_{e}$ is the enforcement cost should the client do not fulfil his financial obligations.

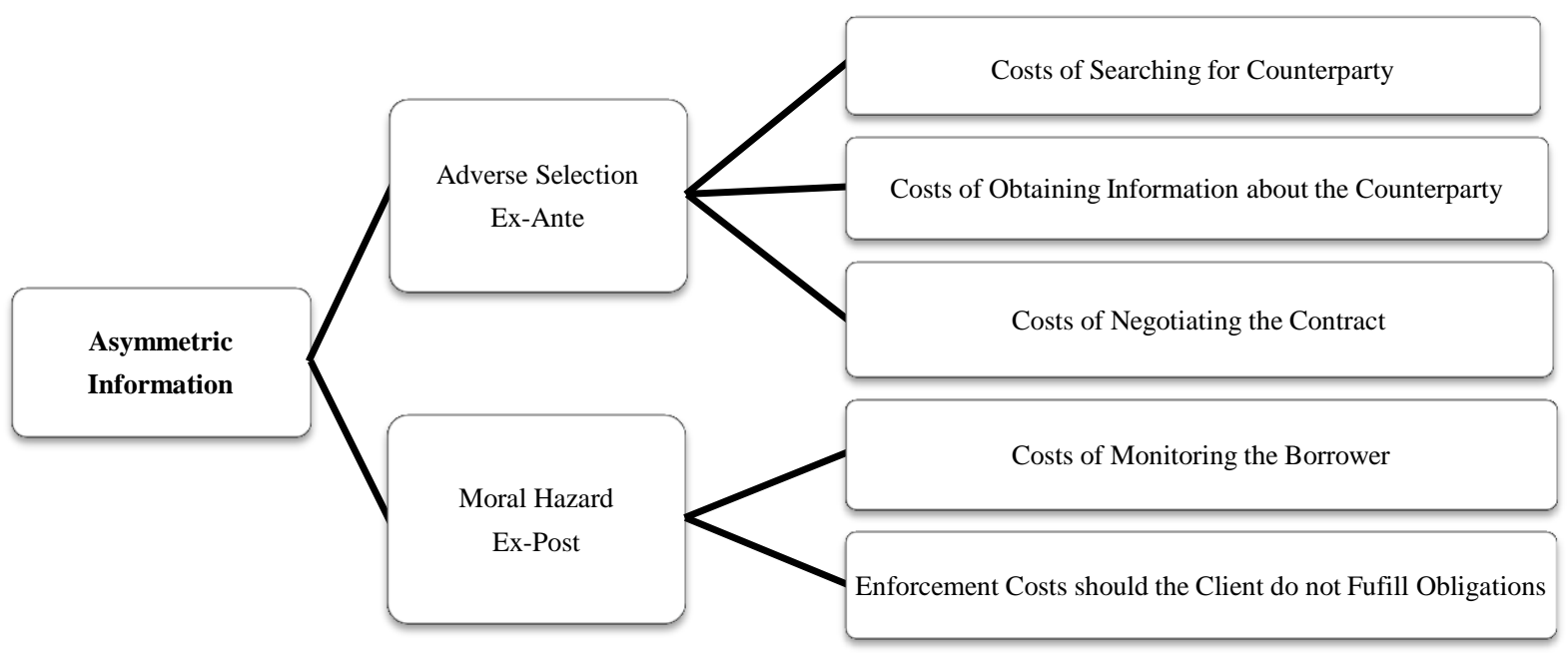

Figure 2. Ex-Ante and Ex-Post costs of bank lending

\subsection{The Cost of Investigating the Moral Hazard}

Moral hazard in Islamic based financial contracts can take different forms, which vary according to the type and nature of the contract between the bank and the client. The most common factors triggering moral hazard are: (i) the borrower using the funds for different purposes than agreed with the bank; (ii) the borrower not reporting the 
profit correctly and truthfully; and (iii) holding inside information used against the interest of the bank.

To tackle the moral hazard problem the bank needs to regularly monitor the performance of the borrowers by obtaining and screening various types of financial information, such as statement of financial position, profit and loss account, cash flow statement, and statement of change in equity. Banks also send inspectors to firms to monitor borrowers' progress.

Investigating moral hazard leads to additional costs to the bank and the outcome of investigation can be either a success or fail. We incorporate this into equation (1) above and we obtain net profit or loss after moral hazard costs as shown in equation 3 below:

$$
E(\Pi)_{B}=\left[P_{\text {Success }} * P R_{s}\left(G R_{s}-C_{\mathrm{Pr}}\right)\right]-\left[P_{\text {Failure }} * L R_{F}\left(G L_{F}-C_{\mathrm{Pr}_{\mathrm{r}}}\right)\right]-M C
$$

Where: $\mathrm{MC}$ is the monitoring cost. If the moral hazard is detected the bank takes back the remaining value of the asset financed and needs to forgo the mark-up. If the moral hazard is not detected then the bank bears the monitoring costs and the borrower continuous to retain the asset.

In terms of the impact on the statement of financial position, the moral hazard effect is more on the asset side rather than the liability side as banks are less likely to not disclose information on their debt and capital as they are subject to heavy regulation.

\section{Resolving Asymmetric Information Problems in Islamic Financial Contacts}

In this section we identify the main modern theories and tools that can be used to deal with the problems associated with adverse selection and moral hazard in Islamic based financial contracts. We synthesise the views given by scholars in this concern and add our articulations of the insights emerging from each theory to produce a cohesive picture of the possible solutions to the asymmetric information problem.

Principles of incentive theory are suggested by number of researchers to deal with principal-agent problems, which have direct relevance to asymmetric information in banking (see for instance: Bannock et al., 2003). The theory assumes that markets are needed to provide managers with the right incentives and to behave rationally (Hayek, 1945). These incentives are considered to be material and their implementation requires co-ordination among market participants (Roemer, 2012). The theory also takes the view that individuals have a natural incentive to behave with certain interest. With asymmetric information presence the project owner is likely to design a contract, which entails a bonus or incentive to stimulate firm manager(s) to reveal any private information about the project. The adoption of an optimal incentive mechanism results in a decrease in the asymmetric information costs (Crémer, Khalil, \& Rochet, 1998; Laffont \& Martimort, 2002). At firm level Nishihara and Shibata (2011) find that owners are more likely to take separating contract with the managers to reduce the information gap and to improve the efficiency of wealth transfer from the firm to the owners.

In Islamic banking context two studies by Dar (2007) and Farook and Farooq (2011) showed the role of incentives in Islamic hedge funds and banks respectively in terms of compatibility and use of debt instruments but this does not extend into showing how to use incentives to reduce asymmetric information in Islamic banks or their contracts. As theoretically explained in the previous section Islamic financial contracts are subject to different level of asymmetric information and hence to apply incentives we first need to consider the nature of the contract used with counterparty and then the level of asymmetric information costs incurred in each stage of their lending process. Overall, for the two Islamic financial contracts discussed in this article we propose using more incentives in mudaraba than in musharaka as in the former the bank client is more likely to hide material information, particularly before receiving the funding from the bank. The financial circumstances of the client may also change in the foreseeable future without being revealed to the bank. Examples of incentives that can be given by the Islamic bank include offering more flexibility of payment in the event of disclosing more information about personal liabilities or reducing the cost of funding the assets.

Signalling is another theory, which is widely used by scholars to explain the information flow from banks to investors and how this can be improved. For instance, dividend payment is considered as a good signal of bank financial health (Boldin \& Leggett, 1995). However, this does not work as effectively in the case Islamic banks, which tend to adopt the same level of dividends over time due to the extensive use of short-term financing (Hassan et al., 2003). Therefore, dividends are perceived to convey limited information about the financial status of Islamic banks. As an alternative to dividends we suggest in musharaka contracts to use level of earnings to indicate to the bank and its partners about the future prospect of their joint projects. Supporting this notion a study by Raymond (1996) shows that earning announcement is a contributing factor to the reduction in asymmetric information between liquidity traders and informed traders. In mudaraba contracts the bank can use borrower credit score and history as a signal of his ability to meet the future debt obligations. 
Macroeconomic variables including inflation rate and reserve requirements are also found to have direct effect on the risk attitude of banks and consequently on the level of asymmetric information of their loan or security portfolio (Thakor, 1996). In economic uncertainty and distress macroeconomic fundamentals worsen making banks less willing to extend credit and pursue investment opportunities. Besides, in times of economic downturn the level of credit and market risk is high leading to increase in bank losses as many borrowers fail to meet their financial obligations. Therefore, the problem of asymmetric information becomes more evident when the economy is in decline due to deteriorating in the financial position of the bank borrowers. The change in macroeconomic fundamentals are expected to have the same effect on Islamic banks' clients and consequently on the scale of asymmetric information in their contracts. This signifies that Islamic banks like their conventional counterparts need to carry more frequent reviews of loans extended in economic uncertainty, particularly when using mudaraba contract, which carries more risk compared to musharaka contract.

Taking into the account the nature of financial contracts used by Islamic banks or conventional banks with Islamic windows, such as musharaka, there is chance that the information used in the screening of clients to be largely soft, which raises the risk and costs incurred by the bank when assessing their clients. Relationship banking is one possible approach to resolve this problem as it enables better monitoring and screening of borrowers. Banks can also link the risk class of the investment financed to the amount of collateral required from the entrepreneurs as suggested by Gottesman and Robert (2004).

Besides, banks can use their comparative advantage when monitoring clients. Small size banks tend to have the benefit of accessing and processing soft information about small and medium enterprises (SMEs) while large banks are better in screening large corporations because of their economies of scale and scope. Taking into account that the majority of Islamic banks are small it is likely that their information advantage is mainly with SMEs. However, SMEs tend to produce and reveal less information compared to large firms and hence Islamic banks need to be more cautious when lending to SMEs. Islamic banks in this instance should consider adjusting their cost of lending to SMEs to compensate them for the additional costs related to the element of asymmetric information (see Bondt, 2002). This is not applicable to conventional banks with Islamic windows though as the majority of them are large and have high capacity for information gathering.

Islamic finance providers also need to time their lending decisions correctly as economic prospects can change very quickly. By collecting more objective information, particularly in times of uncertainty, banks can better recognize borrowers with high probability of default and hence avoid lending to this group of borrowers. Acting prudently on the approval process based on reduced information gap with borrowers is likely to help banks reduce the risk of losses on their unpaid loans.

Another solution to the adverse selection problem is to ask the potential client for a guarantee, as it would be viewed as a signal of good financial strength of the borrower. The bank can take the action of screening to gather information about the health history of potential clients according to the size of collateral offered by the client and the size of the investment (see Gottesman \& Robert, 2004). The bank customers are monitored by assessing their risk profile and adjusting loan rates to reflect the risks of individual customers.

Finally, when the cost of screening is high Islamic banks are advised to adopt a similar approach to the one used by conventional banks, which follows the credit rationing model. By limiting the amount of credit extended to each individual borrower the bank is likely to limit its total losses. Then when the bank develops a good knowledge of the borrower or market area, after a period of time, it may decide to alter the level of credit extended to the borrower or to the market place.

\section{Conclusion}

The topic of asymmetric information has been widely investigated in conventional finance context and is said to result in credit rationing (Stiglitz \& Weiss, 1981) inefficient allocation of capital (De Wet, 2004) unfair pricing of stocks (Myers \& Majluf, 1984) change in the cost of trading (Ravi \& Hong, 2015) and poor investment decisions (Morellec \& Schühoff, 2011). However, only limited research exists on asymmetric information from an Islamic perspective, particularly with reference to mudaraba and musharaka contracts and how to reduce the ex-ante and ex-post asymmetric information costs in Islamic based financial contracts using the relevant principles of conventional finance.

In this research paper we first discussed how gharar is observed in modern financial contracts and how gharar affects the level of asymmetric information. Next we presented theoretical evidence on how asymmetric information in the two main Islamic financial contracts, mudaraba and musharaka, affects bank profit position. The models show how the bank yield changes when the loan is extended to bad borrowers instead of good borrowers and the impact on the bank overall cost. Then, a number of theories were used to provide solutions to 
the problem of adverse selection and moral hazard in Islamic financial contracts including incentive theory, signalling theory and relationship banking.

The analysis presented in this article suggests that Islamic financial contracts are subject to different type of asymmetric information (gharar) related problems at both the ex-ante and ex-post stages of the lending process. Therefore, Islamic banks or conventional banks with Islamic windows need, in the first place, to identify the factors contributing to the element of gharar in the financial contract and then use relevant conventional approaches to reduce the information gap between them and their clients. However, each approach adopted should be applied with caution bearing in mind the unique features of Islamic banking and finance.

Taking into account the portfolio of Islamic banks and in order to minimise losses caused by the asymmetric information Islamic banks need to use more secure financing, particularly with SMEs, which tend to be more financially venerable when the economy is in decline. Islamic banks can also adjust their loan pricing to reflect the new lending risks such as credit and market risk and pass some of their costs to borrowers. The bank loan review, nonetheless, should be separate from the lending function in order to guarantee that all interests, including those of the borrowers, are met and that all parties receive fair treatment.

Finally, as the financial and economic theory focuses primarily on monetary losses attributed to asymmetric information future research may consider looking into the relationship between individuals' financial behaviours and asymmetric information. In Islamic finance, in particular, both banks and their clients are expected to adhere to the moral and virtues of Sharia. Therefore, it will be interesting to investigate the social implications of asymmetric information on Islamic banks and their contracts. Another avenue of research which is beyond what is covered in this article is to investigate the pricing of Islamic financial contracts under asymmetric information.

\section{References}

Abosede, A. J., \& Oseni, J. E. (2011). Theoretical analysis of firm and market specific proxis of information asymmetry on equity prices in the stock markets. Australian Journal of Business and Management Research, $1(2), 1-13$.

Ahmad, H. B. (2004). The significance of prohibition of gharar towards the formulation of essentials of contract in Islamic muamalat: An analysis from the Quran and hadith. Al-Bayan Journal of Al-Qur'an \& Al-Hadith, 2, 171-188.

Al-Darir, S. M. A. (2004). Al-gharar al-mani' min sihhati al-mua'malah wa miqdaruhu. Fourth conference of the Shariah Boards of Islamic Financial Institutions, Bahrain.

Al-Saati, A. R. (2003). The permissible gharar (risk) in classical Islamic jurisprudence. Journal of Islamic Economics, 16(2), 3-19. https://doi.org/10.4197/islec.16-2.1

Al-Suwailem, S. (2006). Hedging in Islamic finance. working paper, Islamic Development Bank, Jeddah, May.

Ayub, M. (2007). Understanding Islamic finance. Wiley, Chichester.

Bayless, M. E., \& Diltz, J. D. (1991). The relevance of asymmetric information to financing decisions. Journal of Business Finance \& Accounting, 18(3), 331-344. https://doi.org/10.1111/j.1468-5957.1991.tb00598.x

Berg, N., El-Komi, M., \& Kim, J. Y. (2016). Market segmentation and non-uniform Shariah standards in Islamic $\begin{array}{llllll}\text { finance. Journal of Economic Behavior \& Organization, } & 132, & 39-49 .\end{array}$ https://doi.org/10.1016/j.jebo.2016.03.019

Berger, A. N., Espinosa-Vega, M. A., Frame, W. S., \& Miller, N. H. (2011). Debt maturity, risk and asymmetric information. working paper, International Monetary Fund, Washington DC.

Boldin, R., \& Keith, L. (1995). Bank dividend policy as a signal of bank quality. Financial Services Review, 4, 1-8. https://doi.org/10.1016/1057-0810(95)90013-6

Chong, B. S., \& Liu, M. H. (2009). Islamic banking: Interest-free or interest-based? Pacific-Basin Finance Journal, 17, 125-144. https://doi.org/10.1016/j.pacfin.2007.12.003

Ciner, C., Ahmet, K., \& Karagozoglu, K. (2005). Information asymmetry, speculation and foreign trading activity: Emerging market evidence. International Review of Finance Analysis, 14(4), 407-427.

Crémer, J., Khalil, F., \& Rochet, J. (1998). Strategic information gathering before a contract is offered. Journal of Economic Theory, 81, 163-200. https://doi.org/10.1006/jeth.1998.2415

Dar, H. A. (2007). Incentive compatibility of Islamic financing. In H. Kabir, \& K. L. Mervyn (Eds.), Handbook of Islamic Banking (pp. 85-95). UK: Edward Elgar Publishing Limited. 
https://doi.org/10.4337/9781847205414.00015

De Bondt, G. J. (2002). Retail bank interest rate pass-through: New evidence from the Euro area level. European Central Bank Working Paper Series No. 136, Frankfurt.

El-Gamal, A. M. (2006). Islamic finance: Law, economics, and practice. Cambridge: Cambridge University Press. https://doi.org/10.1017/CBO9780511753756

Fama, E., \& French, K. (2005). Financing decisions: Who issues stocks? Journal of Financial Economics, 76, 549-582. https://doi.org/10.1016/j.jfineco.2004.10.003

Farook, S. Z., \& Farooq, M. O. (2011). Incentive based regulation for Islamic banks. Journal of Islamic Accounting and Business Research, 2, 8-21. https://doi.org/10.1108/17590811111129481

Frank, M., \& Goyal, V. (2003). Testing the pecking order theory of capital structure. Journal of Financial Economics, 67, 217-248. https://doi.org/10.1016/S0304-405X(02)00252-0

Gheeraert, L. (2014). Does Islamic finance spur banking sector development? Journal of Economic Behavior \& Organization, 103, 4-20. https://doi.org/10.1016/j.jebo.2014.02.013

Gottesman, A. A., \& Roberst, G. S. (2004). Maturity and corporate loan pricing. Financial Review, 39(4), 55-77. https://doi.org/10.1111/j.0732-8516.2004.00067.x

Greenwald, B. C., \& Stiglitz, J. E. (1990). Asymmetric information and the new theory of the firm financial constraint and risk behavior. Bell Communication Research, Stanford University, 8(2), 160-165. https://doi.org/10.3386/w3359

Grenadier, S., \& Wang, N. (2005). Investment timing, agency and information. Journal of Financial Economics, 75, 493-533. https://doi.org/10.1016/j.jfineco.2004.02.004

Hassan, K. M., Farhat, J., \& Al-Zubi, B. (2003). Dividend signalling hypothesis and short-term asset concentration of Islamic interest-free banking. Islamic Economic Studies, 11, 1-25.

Hayek, F. (1945). The uses of knowledge in society. The American Economic Review, 35, 519-530.

Hennessy, C., Livdan, D., \& Miranda, B. (2010). Repeated signalling and firm dynamics. Review of Financial Studies, 23, 1981-2023. https://doi.org/10.1093/rfs/hhq004

James, C. (1987). Some evidence on the uniqueness of bank loans. Journal of Financial Economics, 19, 217-235. https://doi.org/10.1016/0304-405X(87)90003-1

Knutsen, S. (2001). Financial fragility or information asymmetry? The Inter-War Banking Crisis in Norway. $5^{\text {th }}$ EBHA Conference, Norway.

Laffont, J., \& Martimort, D. (2002). The theory of incentive. Princeton: Princeton University Press.

Lin, H. C., \& Zeng, T. (2017). Information asymmetry and incentive contracting with the tax department. Review of Accounting and Finance, 16(3), 385-402. https://doi.org/10.1108/RAF-04-2016-0063

Liu, M. H., Margiritis, D., \& Tourani-Rad, A. (2011). Asymmetric information and price competition in small business lending. Journal of Banking and Finance, 35, 2189-2196. https://doi.org/10.1016/j.jbankfin.2011.01.022

McConnell, J., \& Muscarella, C. (1983). Corporate capital expenditure decisions and the market value of a firm. Journal of Financial Economics, 14, 399-422. https://doi.org/10.1016/0304-405X(85)90006-6

Medhioub, I., \& Chaffai, M. (2018). Islamic finance and herding behaviour: An application to Gulf Islamic stock markets. Review of Behavioral Finance, 10(2), 192-206. https://doi.org/10.1108/RBF-02-2017-0014

Miskin, F. S. (1990). Asymmetric information and financial crises: A historical perspective. Working paper, The National Bureau of Economic Research, Massachusetts.

Morellec, E., \& Schürhoff, N. (2011). Corporate investment and financing and asymmetric information. Journal of Financial Economics, 99, 262-288. https://doi.org/10.1016/j.jfineco.2010.09.003

Myers, S., \&Majluf, N. (1984). The determinants of corporate borrowing. Journal of Financial Economics, 5, 147-175. https://doi.org/10.1016/0304-405X(77)90015-0

Nagaoka, S. (2010). Reconsidering mudarabah contracts in Islamic finance: What is the economic wisdom (hikmah) of partnership-based instruments? Review of Islamic Economics, 13(2), 65-79.

Nehad, A., \& Khanfar, A. (2016). A Critical analysis of the concept of gharar in Islamic financial contracts: 
Different perspective. Journal of Economic Cooperation \& Development, 37(1), 1-23.

Nishihara, M., \& Shibata, T. (2011). The effects of costly exploration on optimal investment timing. Review of Financial Economics, 20, 105-112. https://doi.org/10.1016/j.rfe.2011.06.001

Nordin, N., Abdul Aziz, S., Ahmad, A. A., \& Daud, N. (2014). Contracting with gharar (uncertainty) in forward contract: What does Islam says? Asian Social Science, 10(15), 37-47. https://doi.org/10.5539/ass.v10n15p37

Nyoni, Th. (2018). Information asymmetry in the banking sector: A Zimbabwean scenario. International Journal of Marketing \& Financial Management, 6(1), 45-51.

Ordoňez, G. (2013). The asymmetric effects of financial frictions. Journal of Political Economy, 121(5), 844-895. https://doi.org/10.1086/673886

Padi, C. (2014). Understanding riba and gharar in Islamic finance. Journal of Islamic Banking and Finance, 2(1), 249-259.

Petersen, M. A., \& Rajan, R. G. (2002). Does distance still matter? The information revolution in small business lending. The Journal of Finance, 6, 2533-2570. https://doi.org/10.1111/1540-6261.00505

Phylaktis, K., \& Chen, L. (2010). Asymmetric information, price discovery and macroeconomic announcements in FX market: Do top trading banks know more? International Journal of Finance \& Economic, 15(3), 228-246.

Pike, R., Cheng, N. S., Karen, C., \& Dawne, L. (2005). Trade credit terms: Asymmetric information and price discrimination: Evidence from three continents. Journal of Business Finance \& Accounting, 32(5/6), 1197-1236. https://doi.org/10.1111/j.0306-686X.2005.00627.x

Ravi, R., \& Hong, Y. (2015). Information asymmetry around S\&P 500 index changes. Review of Accounting and Finance, 14(2), 106-127. https://doi.org/10.1108/RAF-04-2014-0046

Raymond, M. B. (1996). Changes in asymmetric information at earnings and dividend announcements. Journal of Business Finance \& Accounting, 23(3), 359-378. https://doi.org/10.1111/j.1468-5957.1996.tb01127.x

Roemer, J. E. (2012). Ideology, social ethos, and the financial crisis. Journal of Ethics, 16, $273-303$. https://doi.org/10.1007/s10892-011-9115-1

Shekari, M. D. S., \& Jamshidinavid, B. (2017). Study of informationasymmetry effect on price synchronism in Tehran Stock Exchange. International Journal of Economics and Financial Issues, 7(4), 343-346.

Shibata, T., \& Nishihara, M. (2012). Investment timing with incentive-disincentive contracts under asymmetric information. Technology and Investment, 3, 74-86. https://doi.org/10.4236/ti.2012.32011

Steijvers, T., \& Voodeckers, W. (2009). Collateral and credit rationing: A review of recent empirical studies as a guide for future research. Journal of Economic Surveys, 23(5), 924-946. https://doi.org/10.1111/j.1467-6419.2009.00587.x

Stiglitz, J. E., \& Weiss, A. (1981). Credit rationing in markets with imperfect information. American Economic Review, 71, 393-410.

Thakor, A. (1996). Capital requirements, monetary policy and aggregate bank lending: Theory and empirical evidence. Journal of Finance, 51, 279-324. https://doi.org/10.1111/j.1540-6261.1996.tb05210.x

Thomas, A. S. (1995). What is permissible now? Singapore: First Printers.

Wet, W. A. (2004). The role of asymmetric information on investments in emerging markets. Economic Modelling, 21, 621-630. https://doi.org/10.1016/j.econmod.2003.09.002

Yasushi, S. (2013). A post-keynesian perspective on Islamic prohibition of gharar. International Journal of Islamic and Middle Eastern Finance and Management, 6(3), 200-210. https://doi.org/10.1108/IMEFM-Sep-2012-0086

\section{Copyrights}

Copyright for this article is retained by the author(s), with first publication rights granted to the journal.

This is an open-access article distributed under the terms and conditions of the Creative Commons Attribution license (http://creativecommons.org/licenses/by/4.0/). 